\title{
Semen quality, lipid peroxidation, and seminal plasma antioxidant status in horses with different intensities of physical exercise
}

\author{
Helena Härtlová1, Radko Rajmon', Iva Krontorádová ${ }^{1}$, Jiř́i Mamica², Lukáš Zita3 , \\ Petra Klabanová ${ }^{1}$, Antonín Černocký ${ }^{2}$ \\ ${ }^{1}$ Czech University of Life Sciences in Prague, Faculty of Agrobiology, Food and Natural Resources, \\ Department of Veterinary Sciences, Prague, Czech Republic \\ ${ }^{2}$ State Provincial Stud Farm in Tlumačov, Czech Republic \\ ${ }^{3}$ Czech University of Life Sciences in Prague, Faculty of Agrobiology, Food and Natural Resources, \\ Department of Animal Husbandry, Prague, Czech Republic
}

Received November 27, 2011

Accepted October 23, 2012

\begin{abstract}
The aim of this study was to compare markers of semen quality, sperm membrane damage, and the seminal plasma antioxidant activity in warmblood stallions with and without sport workload stress. Four stallions were used for breeding only (control) and four both for breeding and competition in jumping. Semen samples were collected at 14-day intervals (from June to August) from each stallion (5 ejaculates per stallion). Immediately after sperm collection, a conventional examination of the ejaculate was processed. Catalytic activities of enzymes aspartate aminotransferase, alanin aminotransferase, glutathione peroxidase, superoxide dismutase and indicator of lipoperoxidation $-\mathrm{F}_{2 \alpha}$ isoprostanes were measured in samples of seminal plasma. Contrary to basic semen quality indicators, the values of seminal plasma $\mathrm{pH}$, aspartate aminotransferase and alanin aminotransferase were significantly $(P<0.05)$ impaired in the physically stressed stallions. Also, the level of $\mathrm{F}_{2 \alpha}$ isoprostanes and the activity of superoxide dismutase were significantly $(P<0.05)$ increased by stress. The antioxidant activities of superoxide dismutase and glutathion peroxidase increased during the monitored period and reflected changes in $\mathrm{F}_{2 \alpha}$ isoprostane concentration. We can conclude that even the conventional basic sperm indicators stay within the reference ranges of the biochemical indicators of seminal plasma such as $\mathrm{pH}$ or AST/ALT activity may be negatively influenced by sport workload stress. Increased concentrations of $\mathrm{F} 2 \alpha$ isoprostanes indicate that lipoperoxidation can be a mechanism of cell membrane destabilization, which is counteracted by an increase of antioxidant enzyme activities. This is the first report of oxidative stress symptoms in normospermic equine semen in relation to stallion sport workload.
\end{abstract}

$F_{2 \alpha}$ isoprostanes, antioxidative enzymes, sperm, stallions

Reproductive capability of stallions is considerably influenced by the quality of their sperm. Indicators such as percentage of live sperm, motility and others are regularly tested (Věžník et al. 2004) although they do not necessarily correlate with the fertility of stallions (Magistrini et al. 1996). Thus, basic examination is supplemented by other methods focusing on sperm quality observation. Due to disrupted human male fertility, since the 1990s much attention has been paid to the loss of functionality and integrity of sperm membranes by reactive oxygen species - ROS (Aitken and Baker 2004). Although lowlevel ROS generation appears to be important in the regulation of the physiological function of sperm (Sanocka et al. 1997), an increase in ROS non-regulated by the production of antioxidants causes oxidative stress (Aitken 2006). Such situation occurs in processes that increase the tissue and cell oxygen requirements, e.g. physical exercise (Avellini et al. 1999). Spermatozoa have a higher unsaturated fatty acid and sterol content. Hence, they are more susceptible to oxidative stress due to lipid peroxidation sperm membranes in the presence of ROS (Aziz et al. 2004). $\mathrm{F}_{2 \alpha}$ isoprostanes, the end-products of lipid peroxidation, is a specific and quantitative marker of oxidative stress (Khosrowbeygi and 
Zarghami 2005). Sperm damage through oxidative stress results in increased membrane permeability to enzymes and other substances, and therefore, reduced metabolic activity of sperm (Storey 1997). Changes in the activity of enzymes such as aspartate aminotransferase (AST) or alanine aminotransferase (ALT) in stallion semen plasma are associated with defects of sperm membranes (Colebrander et al. 1992).

Enzymatic and non-enzymatic antioxidants play a very important role in prevention of the effects of ROS. Lack of these antioxidants increases vulnerability of tissues and cells to oxygen reactive forms and increases the risk of oxidative stress (Aitken and Baker 2004). The amount of cytosol in spermatozoa is limited, thereby limiting the antioxidant capacity. Antioxidant enzymes in seminal plasma such as glutathione peroxidase (GPx), superoxide dismutase (SOD), glutathione reductase and catalase therefore play a major role in protecting spermatozoa against lipid peroxidation (Baumer and Ball 2000).

The aim of this study was to compare markers of semen quality, sperm membrane damage, and the seminal plasma antioxidant capacity in stallions with different intensities of physical exercise.

\section{Materials and Methods}

Eight fertile warmblood stallions between 6 and 10 years of age with a body weight of $550 \pm 30 \mathrm{~kg}$ were used for the experiment. Their diet was balanced with the requirements of the NRC (2007) and water was available ad libitum. Four stallions were used for breeding only (non-stressed control group), and four horses were used for both breeding as well as standard training and competition in jumping (stressed group).

Semen samples were collected with an artificial vagina (Hanover model, Minitüb, Germany) at 14-day intervals (from June to August) from each stallion (5 ejaculates per stallion). Immediately after sperm collection, conventional examination of the ejaculate (volume, colour, motility, concentration and the hypo-osmotic swelling test) was performed in accordance with Věžník et al. (2004) in the laboratory of the Municipal Stud Farm in Tlumačov. After $\mathrm{pH}$ detection, the raw sperm was centrifuged at $2000 \times \mathrm{g}$ for $10 \mathrm{~min}$ at $4{ }^{\circ} \mathrm{C}$. Samples of seminal plasma were stored at $-70^{\circ} \mathrm{C}$.

The catalytic activities of ALT (alanin aminotrasferase) and AST (aspartate aminotrasferase) enzymes were measured by commercial assay kits (Randox Laboratories Ltd, UK). The seminal plasma concentration of $F_{2}$ isoprostanes was determined by enzyme immunoassay using the commercially available 8 -isoprostane $\mathrm{ACE}^{\mathrm{TM}}$ Elisa kit (Cayman Chemical Company, Ann Arbor, MI, USA). The activity of glutathione peroxidase (GPx) was determined in accordance with Paglia and Valentin (1967) using commercial kits RS 505 Glutathion Peroxidase - Ransel (Randox Laboratories Ltd, UK). The activity of superoxide dismutase (SOD) was measured by colorimetric assay using a commercially available colorimetric method SD 125 Superoxid dismutase - Ransod (Randox Laboratories Ltd, UK).

Statistical analysis of the data was performed by two-way analysis of variance with treatment and time interactions using the GLM procedure of SAS (SAS Institute Inc. 2003). Differences were considered significant with $P<0.05$.

\section{Results}

No major differences were found between the two stallion groups comparing the average rates of conventional qualitative and quantitative indicators.

The average $\mathrm{pH}$ of seminal plasma was significantly $(P<0.05)$ influenced by both the term of collection as well as the physical exercise stress (Table 1). Except for the last collection, when the average $\mathrm{pH}$ of seminal plasma in the physically stressed stallions significantly $(P<0.05)$ increased, this indicator was higher in non-stressed stallions. The activities of AST and ALT enzymes in the seminal plasma were significantly $(P<0.05)$ influenced by the group of animals; tending to be higher in the physically stressed stallions than in the non-stressed ones, particularly in case of AST (Table 1).

Also, the concentration of $\mathrm{F}_{2 \alpha}$ isoprostanes in the seminal plasma differed significantly $(P<0.05)$ between the groups of animals. Despite the large variability of individual data, the average values of $\mathrm{F}_{2 a}$ isoprostanes tended to be higher in the physically stressed group (Table 2).

On the contrary, the GPx activity was influenced by the collection term only. The average concentrations were higher in the second half of the experiment $\left(3^{\text {rd }}-5^{\text {th }}\right.$ sampling, Table 2$)$. 
Table 1. Average values of $\mathrm{pH}$, aspartate aminotransferase, alanin aminotransferase activity in seminal plasma of physically stressed and non-stressed stallions in single collections.

\begin{tabular}{|c|c|c|c|c|c|c|c|c|c|}
\hline \multirow{2}{*}{$\begin{array}{l}\text { Semen } \\
\text { indicators }\end{array}$} & \multirow{2}{*}{$\begin{array}{c}\text { Semen } \\
\text { collection }\end{array}$} & \multirow[b]{2}{*}{$\mathrm{n}$} & \multicolumn{3}{|c|}{ Stallions } & \multicolumn{3}{|c|}{ Significance } & \multirow{2}{*}{ SEM } \\
\hline & & & Stressed & $\mathrm{n}$ & Non-stressed & Collection & Group & Collection/group & \\
\hline \multirow[t]{6}{*}{$\mathrm{pH}$} & 1 & 4 & $6.89^{1,2, a}$ & 4 & $7.17^{1, b}$ & \multirow{5}{*}{$* *$} & \multirow{5}{*}{$* *$} & \multirow{5}{*}{$* *$} & \multirow{5}{*}{0.02} \\
\hline & 2 & 4 & $6.93^{1,2, a,}$ & 4 & $7.07^{1, \mathrm{a}}$ & & & & \\
\hline & 3 & 4 & $6.91^{1,2, a}$ & 4 & $7.00^{1, \mathrm{a}}$ & & & & \\
\hline & 4 & 4 & $6.85^{1, \mathrm{a}}$ & 4 & $7.01^{1, \mathrm{a}}$ & & & & \\
\hline & 5 & 4 & $7.07^{2, \mathrm{a}}$ & 4 & $7.06^{1, \mathrm{a}}$ & & & & \\
\hline & 1 & 4 & $7.48^{1, \mathrm{a}}$ & 4 & $3.33^{1, b}$ & \multirow{5}{*}{ NS } & \multirow{5}{*}{$* *$} & \multirow{5}{*}{ NS } & \multirow{5}{*}{0.47} \\
\hline \multirow{5}{*}{$\begin{array}{l}\text { AST } \\
\left(\mu \mathrm{kat} \cdot \cdot^{-1}\right)\end{array}$} & 2 & 4 & $5.75^{1, \mathrm{a}}$ & 4 & $1.59^{1, \mathrm{~b}}$ & & & & \\
\hline & 3 & 4 & $4.92^{1, \mathrm{a}}$ & 4 & $2.07^{1, \mathrm{a}}$ & & & & \\
\hline & 4 & 4 & $6.19^{1, \mathrm{a}}$ & 4 & $2.42^{1, \mathrm{~b}}$ & & & & \\
\hline & 5 & 4 & $5.02^{1, \mathrm{a}}$ & 4 & $3.15^{1, \mathrm{a}}$ & & & & \\
\hline & 1 & 4 & $0.26^{1, \mathrm{a}}$ & 4 & $0.09^{1, b}$ & \multirow{5}{*}{ NS } & \multirow{5}{*}{$* *$} & \multirow{5}{*}{ NS } & \multirow{5}{*}{0.02} \\
\hline \multirow{4}{*}{$\begin{array}{l}\text { ALT } \\
\left(\mu \text { kat. } 1^{-1}\right)\end{array}$} & 2 & 4 & $0.09^{1, \mathrm{a}}$ & 4 & $0.19^{1, \mathrm{a}}$ & & & & \\
\hline & 3 & 4 & $0.14^{1, \mathrm{a}}$ & 4 & $0.04^{1, \mathrm{a}}$ & & & & \\
\hline & 4 & 4 & $0.18^{1, \mathrm{a}}$ & 4 & $0.06^{1, \mathrm{a}}$ & & & & \\
\hline & 5 & 4 & $0.18^{1, \mathrm{a}}$ & 4 & $0.07^{1, \mathrm{a}}$ & & & & \\
\hline
\end{tabular}

**significant $(P \leq 0.05)$, NS - non significant, ${ }^{\mathrm{a}, \mathrm{b}}$ in the line with common superscript do not differ significantly as determined by Scheffe's test, ${ }^{1,2}$ in the column with common superscript do not differ significantly as determined by Scheffe's test, SEM - standard error of the mean, AST - aspartate aminotransferase, ALT - alanin aminotransferase

Table 2. Average values of antioxidant enzymes glutathione peroxidase and superoxiddismutase and of $\mathrm{F}_{2 \alpha}$ isoprostanes in seminal plasma of physically stressed or non-stressed stallions in single collections.

\begin{tabular}{|c|c|c|c|c|c|c|c|c|c|}
\hline \multirow{2}{*}{$\begin{array}{l}\text { Semen } \\
\text { indicators }\end{array}$} & \multirow{2}{*}{$\begin{array}{c}\text { Semen } \\
\text { collection }\end{array}$} & \multicolumn{4}{|c|}{ Stallions } & \multicolumn{3}{|c|}{ Significance } & \multirow{2}{*}{ SEM } \\
\hline & & $\mathrm{n}$ & Stressed & $\mathrm{n}$ & Non-stressed & Collection & Group & Collection/group & \\
\hline \multirow{5}{*}{$\begin{array}{l}\text { GPx } \\
\left(\mathrm{U} \cdot \mathrm{ml}^{-1} \cdot \mathrm{min}^{-1}\right)\end{array}$} & 1 & 4 & $431.12^{1, \mathrm{a}}$ & 4 & $426.91^{1, \mathrm{a}}$ & \multirow{5}{*}{$* *$} & \multirow{5}{*}{ NS } & \multirow{5}{*}{ NS } & \multirow{5}{*}{0.93} \\
\hline & 2 & 4 & $417.80^{1, \mathrm{a}}$ & 4 & $473.18^{1, \mathrm{a}}$ & & & & \\
\hline & 3 & 4 & $487.90^{1,2, a}$ & 4 & $515.24^{1, \mathrm{a}}$ & & & & \\
\hline & 4 & 4 & $658.24^{2, a}$ & 4 & $597.25^{1, \mathrm{a}}$ & & & & \\
\hline & 5 & 4 & $580.43^{1,2 a}$ & 4 & $542.57^{1, \mathrm{a}}$ & & & & \\
\hline \multirow{5}{*}{$\begin{array}{l}\text { SOD } \\
\left(\mathrm{U} \cdot \mathrm{ml}^{-1}\right)\end{array}$} & 1 & 4 & $0.86^{1, \mathrm{a}}$ & 4 & $0.63^{1, \mathrm{a}}$ & \multirow{5}{*}{$* *$} & \multirow{5}{*}{$* *$} & \multirow{5}{*}{ NS } & \multirow{5}{*}{0.19} \\
\hline & 2 & 4 & $1.27^{1, \mathrm{a}}$ & 4 & $0.82^{1, \mathrm{a}}$ & & & & \\
\hline & 3 & 4 & $0.72^{1, \mathrm{a}}$ & 4 & $0.91^{1 \mathrm{a}}$ & & & & \\
\hline & 4 & 4 & $0.91^{1, \mathrm{a}}$ & 4 & $1.36^{1, \mathrm{a}}$ & & & & \\
\hline & 5 & 4 & $3.16^{2, \mathrm{a}}$ & 4 & $1.63^{1, b}$ & & & & \\
\hline \multirow{5}{*}{$\begin{array}{l}\text { Isoprostanes } \\
\left(\mathrm{pg} \cdot \mathrm{ml}^{-1}\right)\end{array}$} & 1 & 4 & $146.03^{1, \mathrm{a}}$ & 4 & $123.75^{1, \mathrm{a}}$ & \multirow{5}{*}{ NS } & \multirow{5}{*}{$* *$} & \multirow{5}{*}{ NS } & \multirow{5}{*}{36.7} \\
\hline & 2 & 4 & $237.63^{1, \mathrm{a}}$ & 4 & $190.05^{1, \mathrm{a}}$ & & & & \\
\hline & 3 & 4 & $198.07^{1, \mathrm{a}}$ & 4 & $215.20^{1, \mathrm{a}}$ & & & & \\
\hline & 4 & 4 & $455.40^{1, \mathrm{a}}$ & 4 & $112.25^{1, b}$ & & & & \\
\hline & 5 & 4 & $247.00^{1, \mathrm{a}}$ & 4 & $173.15^{1, \mathrm{a}}$ & & & & \\
\hline
\end{tabular}

**significant $(P \leq 0.05)$, NS - non significant, ${ }^{\mathrm{a}, \mathrm{b}}$ in the line with common superscript do not differ significantly as determined by Scheffe's test, ${ }^{1,2}$ in the column with common superscript do not differ significantly as determined by Scheffe's test, SEM - standard error of the mean, GPx - glutathione peroxidase, SOD - superoxiddismutase 
The SOD activity was significantly $(P<0.05)$ influenced by both the stallion groups and the term of collection as well. This was due to its significant increase in the exercised groups at the end of the experiment ( $5^{\text {th }}$ sampling, Table 2$)$.

\section{Discussion}

All of the conventional semen indicators were within the reference ranges (Juhasz et al. 2000; Věžník et al. 2004) and did not differ significantly between the groups of stallions. Thus, all the monitored stallions met the conditions of applicability for artificial insemination. Nevertheless, conventional assessment of semen immediately after collection does not capture $100 \%$ of the spermatozoa fertility, as confirmed by differences e.g. in spermatozoa viability tests (Colebrandner et al. 2003). The reason may be changes in some biochemical indicators of seminal plasma (Podstawski et al. 2007).

The average $\mathrm{pH}$ of semen in both groups of stallions was lower than the reference range (Věžník et al. 2004), which could negatively influence spermatozoa quality (Mocé and Graham 2008). Stallions under a workload tended to have a lower $\mathrm{pH}$ than those without a workload. Their $\mathrm{pH}$ levelled itself out toward that of the non-stressed group just at the end of the monitored period, i.e. the end of the sport season. Stallions under a workload also showed significantly higher activities of AST and ALT. Values of AST and ALT activities were generally higher than those reported by Věžník et al. (2004) and values in the stressed group even slightly exceeded the range reported by Pesch et al. (2006). It is generally accepted that increased activities of these intracellular enzymes in seminal plasma correlate with defects of the spermatozoa membranes (Katila 2001). Therefore, it is obvious that although the monitored groups of stallions did not differ significantly in classic semen quality indicators, the evaluation of seminal plasma $\mathrm{pH}$ and AST or ALT revealed differences between these groups to the detriment of the working stallions.

Concentrations of $\mathrm{F}_{2 \alpha}$ isoprostanes were significantly influenced in horses of the experimental group. Predominantly higher concentrations of $\mathrm{F}_{2 \alpha}$ isoprostanes in the seminal plasma were observed in the exercise-stressed stallions. $\mathrm{F}_{2 \alpha}$ isoprostanes are stable end-products of lipid peroxidation of the spermatozoa membrane and therefore can be associated with overproduction of ROS during exercise (Morrow and Roberts 1997; Kirschvink et al. 2002).

The organism is protected from overproduction of ROS by the antioxidant system (Baumer and Ball 2000). In our experiment, the activity of GPx in group of stressed stallions was significantly increased simultaneously with the greatest increase of the F2 $\alpha$ isoprostanes concentration. The activity of SOD significantly increased at the following $\left(5^{\text {th }}\right)$ collection. This is in agreement with our assumption that the defense systems will be enhanced in the semen of stallions with higher concentrations of F2 $\alpha$ isoprostanes.

Our data show that even the conventional basic sperm indicators within the reference ranges for biochemical indicators of the stallion seminal plasma such as $\mathrm{pH}$ or AST/ALT activity may be negatively influenced by sport workload stress. Increased concentrations of F $2 \alpha$ isoprostanes indicate that lipoperoxidation can be a mechanism of cell membrane destabilization, which is counteracted by an increase of antioxidant enzyme activities.

\section{Acknowledgements}

We thank Mrs. Lois Russell for her editorial assistance with this manuscript. This work was supported by grant MSM 6046070901.

\section{References}

Aitken RJ 2006: Sperm function test and fertility. Int J Androl 9: 69-75

Aitken RJ, Baker MA 2004: Oxidative stress and male reproductive biology. Reprod Fertil Dev 16: 581-588 
Avellini L, Chiaradia E, Gaiti A 1999: Effect of exercise training, selenium and vitamin E on some free radical scavengers in horses (Equus caballus). Comp Biochem Physiol B 123: 147-154

Aziz N, Saleh, RA, Sharma, RK, Lewis-Jones, I, Esfandiari, N, Thomas AJ, Agarwal, A 2004: Novel association between sperm reactive oxygen species production, sperm morphological defects and the sperm deformity index. Fertil Steril 81: 349-354

Baumer J, Ball BA 2005: Determination of gluthatione peroxidase and superoxide dismutase-like activities in equine spermatozoa, seminal plasma, and reproductive tissue. Amer J Vet Res 66: 1415-1419

Baumer J, Ball BA Gravance CG, Medina V, Davies-Morel MCG 2000: The effect of reactive oxygen species on equine sperm motility, viability, acrosomal integrity, mitochondrial membrane potential and membrane lipid peroxidation. J Androl 21: 895-902

Colenbrander B, Fazeli AR, Vanbuiten A, Parleviet J, Gadella M 1992: Assessment of sperm cell-membrane integrity in the horse. Acta Vet Scand Suppl 88: 49-58

Colebranbrander B, Gadella BM, Stout TAE 2003. The predictive value of semen analysis in the evaluation of stallion fertility. Repr Dom Anim 38: 305-311

Juhasz J, Nagy P, Kulcsar M, Huszenicza G 2000: Methods for semen and endocrinological evaluation of the stallion: A review. Acta Vet Brno 69: 247-259

Katila T 2001: In vitro evaluation of frozen-thawed stallion semen: A review. Acta Vet Scand 42: 199-217

Khosrowbeygi A, Zarghami N 2005: Seminal plasma levels of free 8-isoprostane and its relationship with sperm quality parameters. J Clin Biochem 3: 49-52

Kirschvink N, Art T, De Moffarts B, Smith N, Marlin D, Roberts C, Lekeux P 2002: Relationship between markers of blood oxidant status and physiological variables in healthy and heaves affected horses exercise. Equine Vet J Suppl 34: 159-164

Magistrini M, Vidament F, Clement F, Palmer E 1996: Fertility prediction in stallions. Anim Reprod Sci 42: 181-188

Mocé E, Graham JK 2008. In vitro evaluation of sperm quality. Anim Repr Sci 105: 104-118

Morrow DJ, Roberts LJ 1997: The isoprostanes: Unique bioactive products of lipid peroxidation. Prog Lipid Res 36: $1-21$

NRC 2007: Nutrient requirements of horses $6^{\text {th }}$ Ed. National Academy of Sciences Washington, DC

Paglia DE, Valentin WN 1967: Studies on quantitative and qualitative characterization of erythrocyte glutathione peroxidase. J Lab Clin Med 70: 158-169

Pesch S, Bergmann M, Bostedt H 2006: Determination of some enzymes and macro and microelements in stallion seminal plasma and their correlations to semen quality. Theriogenelogy 66: 307-317

Podstawski Z, Kosiniak-Kamysz K, Bittmar A 2007. Relationship between some enzymes activity, morphology and stallion semen quality. Zootehnie si Biotehnologii 40: 152-156

Sanocka D, Miesel R, Jedrzejczak P, Chelmonska-Soyta A, Kurpisz M 1997: Effect of reactive oxygen species and the activity of antioxidant systems on human semen; association with male infertility. Int $\mathrm{J}$ Androl 20: 255-264

Storey BT 1997: Biochemistry of the induction and prevention of lipoperoxidative damage in human spermatozoa. Mol Hum Reprod 3: 203-213

Věžník Z, Švecová P, Zajícová A, Přinosilová P 2004: Repetitorium: Spermatology and Andrology and Sperm Analysis Methodology (in Czech). Brno, 197 s, ISBN 80-86895-01-7 